quite different to that of the steady state. The lecture was illustrated by oscillograms made by Dr. Richardson and his students.

L. Canac (Marseilles) described his work on the acoustics of open-air theatres. Tests of audibility of nonsense syllables have been made in the Roman theatres of Provence and in open country of similar rising contour. The theatre at Orange, in which the majority of the tests were made, has the stage complete with wall. Contrary to what has formerly been held, this backing wall does not act as a reflector to add intensity to the actor's voice but is so disposed, with much ornamental excrescence, to act as a diffusing screen; in fact, to simulate the conditions of the open air. This was confirmed by experiments on audibility at the theatre of Vaisons, where though the wall behind the stage has not survived, one can now hear better than at Orange, and by laboratory experiments in a model section, using ripples or supersonic beams to exemplify the diffusing properties of the irregular wall surface. Whatever the original intention, the actual function of the backing wall was, in Prof. Canac's opinion, to act as a screen to cut off street noise.

P. Fouché (Paris) gave a general account, from the scientific point of view, of the present state of the study of phonetics. The physicist plays his part by determining the relation between the timbre corresponding to different vowels and the shape and natural frequencies of the buccal cavities. The existence of fixed pitches (formants) corresponding to each vowel sound at whatever pitch it may be enunciated is now well established. The physiologist is concerned to measure the muscular effort required to enunciate and to maintain a speech sound-the latter is not constant but diminishes while the physical intensity remains steady. Psychology enters too, for the speaker often has a different 'feeling' for the rate at which he is using energy from that indicated either by muscular measurements or by a microphone measuring physical intensity. M. Fouché urged that the æesthetic aspects of speech should not be ignored. There is a beauty of language as well as a beauty of literature.

This concluded the discussions, but a visit was paid by those taking part in the meetings to the International Exhibition of Scientific Research and Industry, also held to celebrate the centenary, where of special acoustic interest was an electronic model of the ear, built and demonstrated by Dr. Coppée. This consists of a microphone connected through a number of filter eircuits (to represent the resonant properties of the inner ear), each terminating in a thyratron and a flash lamp. The latter simulates the property of nerve fibres by which loudness is measured in terms of the number of messages passing per second to the brain. Thus, if one holds near the microphone a sounding tuning-fork of a frequency corresponding to that of one of the resonant circuits, the corresponding bulb begins to flash, and flashes become more frequent as the fork is brought nearer. The apparatus shows many other features of the sense of hearing. Gramophone records of music heard through the ear of a cat were also played.

At the final session, it was unanimously agreed that those present should form the nucleus of an international conference on acoustics generally, which should be called together every few years and held in a number of European centres in succession. The honorary liaison secretary for this purpose is M. F. Monfort, jun., 32 rue de France, Verviers, Belgium.

\section{DANISH MARINE BOTTOM INVERTEBRATES}

A RECENTLY published handsome volume*, 1 dedicated to the memory of C. G. J. Petersen,
director of the Danish Biological Station for many years, is in the best tradition of Danish oceanographical research, and is a tribute to the undaunted temper of the Danish people, who kept alive the spirit of learning, although surrounded by their enemies.

Petersen and Boysen Jensen had published during 1911-15 their "Animal Communities of the Sea Bottom", dealing with the charting of the fauna of the ocean bed from the Baltic to the Skagerrak by means of the newly invented Petersen grab. It was intended to follow this up by a study of the breeding habits and young of the bottom communities in relation to their importance as food for fishes, but between the Wars attention was diverted to investigations on the fish themselves. Dr. Thorson and his collaborators, many of them well known in the zoological world, began in 1936 an intensive study of the Danish marine fauna, but, "instead of concentrating on the young bottom stages", as Petersen did, have attempted "to trace the species back to the planktonic larval stages". It is here that our knowledge was deficient, yet research from the faunistic, economic or ecological points of view necessitates recognition of the species to which the pelagic larvæ belong. Despite the painstaking work of Mortensen on larval Echinoderms, Lebour on Molluses and Crustacea and D. P. Wilson on Polychætes, most of us get no further than identifying an Auricularia larva, a Nudibranch egg ribbon, a zoca larva or a Spionid metatrochophore. At first, then, much of Dr. Thorson's work was analytical. He must either rear the larvæ from eggs, as has been done so successfully at Plymouth, or trace the stages back to younger and younger larvæ, sketching every 'unknown' alive, in the hope that some day its place in the series will be found and its parents determined. Since these early stages are so sensitive to their environ. ment, it is important to collect them in their own water, and to record temperature, light intensity, salinity, $p \mathrm{H}$, food conditions and enemies. When all this has been done a synthesis from an ecological point of view can be attempted, involving all stages in the life of the animal and its community. "The whole survey," writes Dr. Thorson, "has been carried out in our leisure hours, and enabled us to combine the scientific work with splendid summer holidays."

The plan of campaign was to take vertical plankton hauls at metre intervals, from near the bottom to the surface, in fixed localities, every fortnight throughout the year. Two main sites were chosen, one off the island of Ven (Swedish) and the other at Helsingør (Danish). The former was used until 194l, after which date, owing to the War, the work was transferred to the Danish station. The net hauls were examined as soon as possible by a team of workers sorting, countıng, sketching, recording and, if possible, identifying the species of animals. During the summer pump hauls were taken by pumping 200 (later 100) litres through a No. 12 plankton sieve, starting a few centimetres above the bottom, and repeating at metre intervals, so that nineteen samples were taken

* Meddelelser fra Kommissionen for Danmarks Fiskeri- og Havundersøgelser. Serie: Plankton. Bind 4. No. 1. Gunnar Thorson Reproduction and Larval Development of Danish Marine Bottom Invertebrates, with special reference to the Planktonic Larvæ in the Sound (Øresund). Pp. 523+199 plates. (København: C. A. Reitzels Forlag, 1946.) 
from the 20-metre depth of water. The advantage of this procedure was that the individual samples were transported to the laboratory in water from their own depths. Rearing of the larval stages was carried out in aquaria in the laboratory, and by means of 'bottle collectors' invented for the purpose. These were left submerged in the open sea, at the depth to which certain organisms were accustomed, for six weeks at a time, and then hauled up for inspection. The cage collectors used by Smith in Great Britain were found unsuitable owing to variations in temperature and salinity in Danish waters. 'The bottle collector is like an inverted bell jar, with a stopper at the lower end, protected at the sides by a jacket of pieces of cork held together by netting. It is anchored by stones to the required depth, and is marked by a float on the surface. This open apparatus collects its own sea bed for the delicate larvæ, from the rain of detritus from above, and experience shows that the larvæ are closely adapted to suitable surroundings, dying rather than metamorphosing if the right substratum is not available. The water in the bottle collects the swimming stages. Moreover, after being hauled up, the bottles can be placed on racks and kept as small aquaria. In one locality young bottom stages of seventy invertebrates were secured at a depth of $16 \mathrm{~m}$.

The results of these investigations showed that the dominant groups in the Sound plankton are Lamellibranchs (57.3 per cent), Prosobranchs (12.5 per cent), Polychætes (10.9 per cent) and Echinoderms ( 1.9 per cent). There is a high percentage of Cyphonautes larvæ (12.9 per cent), leaving only 4.5 per cent for all other groups.

Dr. C. B. Jørgensen contributes the section on Lamellibranch larvæ, and was able to identify twenty-three species, the most interesting of which were those of Teredo and the two species of Montacuta. Sixty-one Prosobranchs are known in the larval stage, and of these sixty have a long pelagic life. They are mostly phytotrophic and form the food of herring, mackerel and many invertebrates. About half the 142 species of bottom Polychrtes can be identified in the larval stage, and their success in evading capture by predaceous animals is due to their armour of bristles. Many feed on the larvæ of Lamellibranchs. The percentage of Echinoderm larvæ appears small, until it is realized that these well-known larvæ cannot endure changes in salinity and temperature, and having no hydrostatic apparatus are unable to adjust themselves in depth when an infiltration of less saline waters from the Baltic floods the upper waters of the Sound. Dr. Mortensen considers that the parent stock on the bottom is recruited, not from the larva in the Sound itself, but from the large swarms of the Kattegat. $\mathrm{He}$ found also that the reproductive-rate of these migrants was less in the new habitat. This relation between spawning, larval survival and ecological conditions might be followed up around the shores of Britain in an attempt to explain anomalies of distribution.

Two life-histories that are of special interest are those of Philine aperta and the Holothurian Psolus phantopus.

In the final discussion many valuable generalizations emerge. Evidence goes to show that the larvæ are evenly distributed through the water masses, rarely swarming. In two years only three larvæ of Strongylocentrotus drobachiensis were collected. Is this species, therefore, rare? Yet, if evenly distributed, there would be two and a half milliards in the area. What, then, must be the population of 'common' forms ? Dr. Thorson works out that littorina littorea would have twelve thousand milliard and Mytilus edulis four thousand five hundred milliard larvæ.

The distribution of the larvæ throughout the year enables one to work back to the spawning periods. July has the maximum for all types of larvæe in the Sound, but there are lesser peaks in spring and winter. The minimum is in the late autumn. Compared with fjord conditions, spawning is spread over a long period, not concentrated into a late spring and early summer peak as in the fjords. In the Sound there is a drift of larvæ from the Baltic northwards to the Kattegat, bringing impoverished specimens from the less saline waters. The reverse stream, from the Kattegat southwards, is much richer in individuals. There are also the larvæ developing from the spawn of animals living on the bottom. Analysing these three sources, Thorson found that the Baltic stream from May onwards brings chiefly the larvæ of Littorina littorea and other Prosobranchs, the bottom fauna of the Sound produces non-pelagic larvæ or larvæ with a short pelagic life (for example, Serpula), and the parents in the Kattegat provide 50 per cent or more of the whole stock in the Sound, mostly larvæ with a long pelagic life. As an ecological area, therefore, the Sound supplies very different data from those obtainable in either arctic or tropical regions, where the larvæ have mostly a short pelagic life; and in the temperate zone it is the high proportion of larvæ with a long pelagic life which provides food for the fishes of economic importance. Moreover, this is the group that shows the greatest fluctuation in numbers from year to year.

To sum up, Dr. Thorson's book is a valuable contribution to both analytical and synthetic aspects of the fauna of a marine area. We in Britain can Iearn much from his work and his methods, and not by any means least from his clear, smoothly flowing English and delicate, accurate drawings.

There is a summary at the end of each section, and the final summary is printed also in Danish. An exhaustive bibliography and index are appended. The book is well produced and printed, but its limp covers will soon need replacement in libraries.

N. B. Eatigs

\section{FORTHCOMING EVENTS}

Monday, December I

RoYal Sochery (at Burlington House, Piccadilly, London, W.1), at 2.30 p.m. - Anniversary Meeting.

Tuesday, December 2

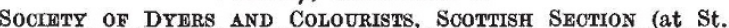
SOCHTY OF DYERS AND COLOURISTS, SCOTIISH SEOTION (at St.
Enoch Hotel, Glasgow), at 7 p.m.-Dr. K. W. Richmond : "Modern

Trends in Hydrogen Peroxide Application".

SOCIETY OF DYFRS AND COLOURISTS, HUDDERSFIELD SECTION (joint meeting with the ROYAI INSTITUTE OF CHEMISTRY, at Field's Café, Westgate, Huddersfleld), at 7.30 p.m.-Dr. W. Baird": "Modern Developments in Synthetic Detergents".

\section{Wednesday, December 3}

Physicat SocIety, Cotour GrodP (in the Lecture Theatre of the Geological Museum, Exhibition Road, London, S.W.7), at 3.30 p.m. Mr. J. Pryce-Jones: "Ultramarine-Natural and Synthetic".

Hispanid and Luso Braziman Councirs (at Canning Honse, 4 Upper Berkeley Street, London, W.1), at 5 p.m.-Mr. Kenneth G. Grubb: "The Great British Explorers of the Interior of South America".

INSTITUTION OF ELECTRICAL ENGINEFRS, RADIO SECTION (at Savoy Place, Victoria Embankment, London, W.C.2), at 5.30 p.m. - Mr. T. C. Macnamara, Mr. A. B. Howe and Mr. P. A. T. Bevan: "The Design and Operation of High-Power Broadcast Transmitter Units with their Outputs Combined in Parallel".

Manohaster Statistical Societr (at the Reform Club, King Street, Manchester), at 5.30 p.m.-Dr. George Gibson: "Modern Distribution of Industrial Activity in the North-West Region". 